\title{
International Retailing Operations Downstream Entry and Expansion via Franchising
}

\author{
Petersen, Bent; Welch, Lawrence S.
}

Document Version

Final published version

Publication date:

1999

\section{License \\ CC BY-NC-ND}

Citation for published version (APA):

Petersen, B., \& Welch, L. S. (1999). International Retailing Operations: Downstream Entry and Expansion via Franchising. Department of International Economics and Management, Copenhagen Business School. Working Paper / Department of International Economics and Management, Copenhagen Business School No. 5-1999

Link to publication in CBS Research Portal

\section{General rights}

Copyright and moral rights for the publications made accessible in the public portal are retained by the authors and/or other copyright owners and it is a condition of accessing publications that users recognise and abide by the legal requirements associated with these rights.

Take down policy

If you believe that this document breaches copyright please contact us (research.lib@cbs.dk) providing details, and we will remove access to the work immediately and investigate your claim. 


\title{
International Retailing Operations: Downstream Entry and Expansion via Franchising
}

\author{
Bent Petersen \\ and \\ Lawrence S. Welch
}

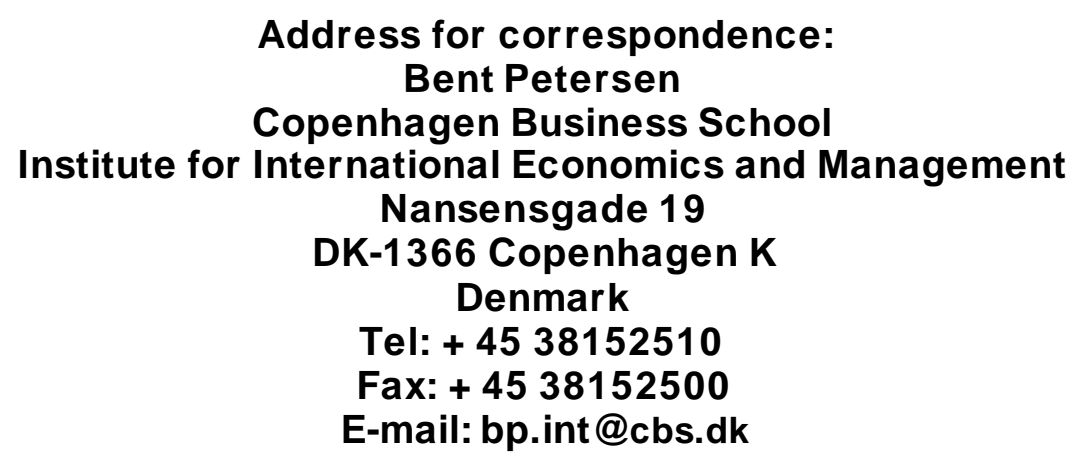

Bent Petersen is Associate Professor of International Business at Copenhagen Business School, D enmark.

Lawrence S. Welch is Professor of International Marketing at the Norwegian School of Management (BI) in O slo and Adjunct Professor, D epartment of Marketing, International Business and Asian Studies, University of Western Sydney-Nepean, Australia. 


\title{
International Retailing Operations: Downstream Entry and Expansion Via Franchising
}

\begin{abstract}
In this article, the shift into international franchising from other forms of operation, rather than the typical home market franchising base is explored. The focus is international retail franchising, based on a study of the Danish clothing and footwear industry. In this study it was found that Danish companies were moving into international franchising as an outcome of a more general shift from upstream wholesaling and subcontracting activities to downstream involvement in retailing activities. Preceding establishments of foreign subsidiaries and company owned retail operations seemed to be important in facilitating the move into franchising.
\end{abstract}

\section{Key Words}

international franchising; international retailing; internationalization; foreign operation mode 


\section{International Retailing Operations: Downstream}

\section{Entry and Expansion via Franchising}

Research on the use of franchising in international operations has tended to concentrate on companies which have built franchising activities first within their domestic market before utilising that experience and the tried franchising system in the international arena (Walker and Etzel, 1973; Hackett, 1976; Walker, 1989; McCosker and Walker, 1992; and McIntyre and Huszagh, 1995). Indeed, this research suggests that franchisors are loath to alter their basic franchising package, once developed domestically, for foreign markets. For example, Walker (1989) found that the bulk of US franchising companies he surveyed had engaged in minimal changes to the marketing mix components of their franchising packages in international operations. Clearly, there are significant benefits in being able to experiment, modify and develop a franchising system within a local market first - learning how to operate the system and to manage a franchised network. If the resulting system and associated learning can be transferred to a foreign location with limited alteration, the transfer process thereby becomes easier and cheaper. Nevertheless, recent US research has stressed the additional demands on firm capabilities as a franchisor moves from domestic to international franchising, as a result of having to adapt to differences in the franchising and cultural environment (Fladmoe-Lindquist, 1996).

While there appears to be a dominant path of domestic to international franchising, there is conceptually no reason why there should not be other patterns of adoption of franchising as a form of international operations. Based on the experience of a small number of Australian companies' international franchising activities, Welch (1990) notes a diverse range of forms and paths to franchising use in international operations. One option used by Australian companies in expanding international activity was to add franchised outlets to existing foreign retail operations as a way of accelerating the process of international market penetration.

In this article, we have sought to extend the investigation of the shift into international retail franchising from a base which includes other forms of foreign operations, but without commensurate domestic franchising development. The aim was to build a framework for understanding how and why franchising may be used as a means of expanding international retail operations at a later stage of internationalisation. The 
circumstances surrounding such a move into - and use of - franchising were investigated. Particular emphasis was given to the steps which precede, and contribute to, the company's ability to make the shift, as well as to other influential factors. In addition, the ways in which companies cope with the demands of what would seem to be an important new approach to international expansion were examined. Given the paucity of research on the shift into international retail franchising, the authors undertook an exploratory study of this shift by Danish clothing and footwear companies. The reporting of the empirical study follows an examination of conceptual issues and pertinent empirical research.

\section{Shift to International Retail Franchising}

Franchising in some respects can be considered an 'awkward' foreign market servicing mode when analysing its use from a theoretical perspective. In this article we will focus on the business format version of franchising. While often categorised as a contractual mode, alongside licensing (Burton, Cross and Rhodes, 1997), in reality it may emerge through a number of other operation mode forms, as shown in Figure 1. Within a generic category of franchising as the ultimate primary means of foreign market exploitation, this may be handled via a wide range of organisational types: for example, direct franchising (exporting equivalent), master franchising or area development (licensing equivalent - see Figure 1 for a definition of these terms and direct franchising), and a wholly owned subsidiary or joint venture (foreign direct investment). These are illustrated in Figure 1, which also indicates that, within the foreign market, franchised activities will often coexist with company-owned operations.

\section{FIGURE 1 ABOUT HERE}

Likewise, there may be very diverse paths into the use of franchising in international operations, contrary to the mainstream path noted earlier, so it is difficult to generalise about reasons for the adoption of franchising. In cases where international franchising use has been preceded by other forms of international operations, there is likely to be a background of relevant international experience and networks on which to draw, even though franchising represents a new area of activity. The background could, of course, be connected with the experience of individuals rather than the company, as in 
the case of Voice of Europe, the Norwegian clothing company. The company moved quickly into international franchising operations in 1988 from a company start of just one year beforehand: the two founders had created and sold, in the 1980s, an international clothing chain (Bik Bok) and stressed that it was not difficult to start another chain because of the knowledge gained and the 'world-wide network of contacts in the industry' which could be readily re-activated (Framnes and Welch, 1992, p. 601).

In other situations the preceding experience might have involved the establishment of a network of facilities - for example, owned retail outlets which are then converted to franchising-based operations. It is of note that a survey of divestment within retail networks in Italy found that a high proportion (78\%) had franchised the divested stores. The foreign component of the sample is not indicated, but one case is mentioned where, after acquisition of the Italian chain Fersina, the French company Elf Atochem converted five out of thirty two retail stores to a franchising basis. The two major reasons expressed by respondent firms in the survey for undertaking the switch to franchising were: to 'develop the franchise network after learning by directly running stores' and to 'generate capital to invest in the franchise network' (Baroncelli and Manaresi, 1997, p. 230). Both reasons indicate an expectation of faster growth through franchising, while in the first reason there is also an expressed expectation of learning benefits from preceding operations being able to be applied. The demands implicit in such examples come in the form of the switch to franchising - the question is how readily such companies can build and apply franchising-specific skills and knowledge, assuming that franchising has not been used in operations elsewhere.

Franchising specific knowledge could, of course, be acquired through the hiring of staff with a background in franchising, or it may well be that having individuals on staff with franchising experience could provide the spark for the initial idea to develop retailing activities through a move into franchising, as in the case of Bally in the UK. In 1982 the Swiss shoe manufacturer Bally began franchising operations in the UK in an effort to extend its penetration in retailing activities. From a manufacturing base in the UK it had previously set up a small number of its own shops and wanted to expand the activity, thereby reducing its reliance on independent retailers. The interest in franchising had apparently been driven by new management staff with experience in franchising (D nes, 1992, p. 57). This example illustrates again the fact that background experience and knowledge relating to a specific operation mode is not always evident from a company's 
operation mode experience, but is also related to the background of individuals working within the company or hired by it (Welch and Welch, 1996 and Petersen and Pedersen, 1997).

It is, of course, possible, as in the Elf Atochem case, to convert existing outlets on a piecemeal, experimental basis thereby minimising risk exposure and using the initial conversions as learning sites. This is similar to the approach used by many franchising companies in developing international operations: a foreign market is entered through owned outlets (for example, via a subsidiary), and then deeper penetration occurs on a franchising basis, after suitable adjustments to the franchising package have been made, based on differences in the market which are found necessary to respond to. In such cases, the companies concerned already possess a base in franchising, so that the owned

outlets are merely a stepping stone to the continuation of their international expansion via franchising. In the former situation, the learning demands are about using franchising, as the retail base already exists in the foreign market. Clearly, there is a wide range of types of preparation from pre-existing operations as a prelude to the move into franchising in the foreign market, making the process easier or more difficult depending on the applicability of the former experience to the new situation. This can be classified by types of learning connected with: franchising, domestic and/or international; and nonfranchising operations, domestic and/ or international, including experience within the specific market in question.

\section{FIGURE 2 ABOUT HERE}

Figure 2 attempts to depict some of the variation in paths into franchising in the foreign market, producing different demands on the company in terms of the type of learning required. The step from non-franchising domestic operations into franchising within a foreign market, with no previous experience in any other form of international operations, would appear to be the most difficult path to undertake from a learning perspective. There is little evidence to indicate how companies have performed when converting into franchising in international operations without preceding experience, but franchising would seem to be no different from other foreign market servicing modes in requiring mode-specific knowledge and skill development associated with organising the franchising package, marketing the system and managing the resulting network. 
Internationalising franchising companies often stress the learning benefits of operating the franchise system first in the domestic market - honing the training program, adjusting package components, refining the operations manual, and so on, as a result of experience in the domestic market (Welch, 1990).

The situation is compounded in franchising operations in that most foreign franchising is carried out other than through direct franchising, using another operation mode (see Figure 1), so there is the inevitable additional mode learning that has to take place which is not franchising-specific. As it is, few companies are able to maintain a direct franchising approach for very long once the extent and scale of international activities expands. The use of the master franchising approach is a common response by companies with limited experience in international franchising because it transfers the responsibility for directly developing and managing the foreign franchising activity to a foreign operator, and could be said therefore to reduce the learning demands of, and financial and other commitments to, the foreign operation, compared to other forms such as a wholly owned subsidiary. It does not remove them, however, merely changing the mix of activities and commitments, with a focus on managing the technology transfer process to, and the longer term relationship with, the master franchisee. The use of a particular operation form as the basis of franchising in the foreign market might be facilitated by experience with this form, albeit for non-franchising purposes, in other foreign markets. A case in point would be where a company has used a sales subsidiary in another foreign market to facilitate its exporting operations in that market. Thus, a diverse range of international experience may be able to be used in activities surrounding the foreign franchising exercise even though it is not directly related to the practice of franchising itself.

\section{Manufacturer to International Retail Franchisor?}

The difficulties and learning demands of the various paths into foreign franchising noted above would appear to be exacerbated in situations where a company is seeking, at the same time, to expand into another branch or industry in which it has had no previous background. An example is when a manufacturer attempts to move into international retailing activities, using the franchising method. If the company has had no international experience in other forms, it has to devel op a wide set of new activities and skills, including the step into retailing. There appears to be a developing trend in this regard in 
the clothing sector globally as companies face a combined squeeze from powerful retailers and cost pressures from new low cost suppliers. Moving downstream into retailing has been seen as one way of escaping this squeeze, while franchising has come to be regarded as one way of facilitating the transition. For example, the role of franchising in giving French clothing manufacturers direct access to retail outlets has been noted by Lewis (1993), who commented (p.1): 'For manufacturers, franchised retailing creates a captive market at the retail level. It is the quickest and cheapest way to acquire or expand a retail function'. Similarly, Hong Kong clothing companies appear to be moving upstream into design and downstream into distribution and retailing as a way of remaining viable operators in the clothing sector (G ranitsas, 1998).

The evidence from international franchising and retailing studies would seem to indicate that the shift into international retailing, whether via franchising or not, has tended to be undertaken from a base in domestic retailing, that is, it mirrors the pattern noted earlier for franchisors in general (Walker, 1989; Treadgold, 1991; Burt, 1993; Dawson, 1994; and Alexander, 1996). In fact, some writers are at pains to stress the differences between the internationalisation of retailing and manufacturing activities. For example, D awson (1994, p. 278) observes: 'The process (internationalisation in retailing), for many reasons, is substantially different from the internationalisation process in manufacturing firms'.

The shift into international retail franchising by manufacturers, however, might conceivably be handled more readily in situations where a company is able to support the move through the strength of a well known brand name and established international market presence (Segal-Horn and Davison, 1992). These characteristics may, in fact, provide an important basis for the shift - a market advantage that can be further exploited through direct involvement in downstream retailing operations. From such a base, for the company, there would seem to be little point in taking the step if it is kept as a purely domestic activity. While it may not have direct experience in retailing, if a company has developed international operations through exporting an end product that is sold to the final customer in retail outlets, it is likely to have built up some understanding of the context, characteristics and requirements of pertinent foreign retailing activities. Intermediaries are used commonly as the direct contact point to the retailers, but exporters who are active in foreign market development tend to be involved in visits to 
retailers, market studies, promotional activities, and the like, resulting in not only knowledge of the market and customers, but also of the retailing system.

An associated aspect of internationalisation by manufacturers is the tendency over time to expand the content of the product offering. Comprehensive Finnish research found a pattern of evolution in international operations from a basic product to a more complex and enhanced package which frequently included additions of service and knowhow components, with some companies developing to the point where they were able to market what could be called an integrated system (Luostarinen, 1979 and Luostarinen et al., 1994). The learning and competence development flowing from this process may well be capable of being bundled into the business format franchising format which represents a type of systems package. Much of the expanded product offering will have been in response to the additional demands of servicing foreign customers, as well as foreign intermediaries and other network partners, although it still may require a considerable step to achieve retail franchising competence.

There are, of course, areas of specialised knowledge of retailing operations with respect to the product in question which the exporter can never hope to acquire without direct involvement, but it is possible to move a considerable distance along the knowledge and network trail without first becoming a retailer. It can be argued also that establishing and managing an intermediary in a foreign market (to handle exports) is not far removed from the situation of using a master franchisee to operate the franchising system in the same market - thereby potentially acting as an effective preparatory stepping stone to a move into retail franchising operations via a master franchising approach. The limitations of a lack of expertise in retailing could be further eased in situations where the company is able to use a 'shop-in-shop' strategy initially, thereby operating under the umbrella of an established retail establishment, with the potential to access its retail experience and expertise in the local market.

Clearly then, while the step into international retail franchising from a manufacturing base would seem to be a major shift, there are development processes that are capable of preparing a company for the move, while the path might be further eased by the form and extent of the foreign franchising activity: an incremental approach is feasible. 


\section{Reasons for Shift to International Retail Franchising}

The discussion so far has indicated that an important part of the explanation for the shift into international retail franchising, whether in the same branch or not, lies in the type of preceding experience of the firm. Frequently, too the stimulus for the move emanates from this experience, domestic or international: for example, an expanding domestic franchising network often attracts interest from potential international franchisees and is a factor in building sufficient confidence to pursue international possibilities (Welch, 1990). As noted earlier, preceding international experience of the company, as well as the individuals within, may prepare it for the international retail franchising step in a variety of ways, intended and unintended.

Despite these various potential forms of preparation, the switch from a manufacturing base requires additional explanation. The Bally case referred to earlier demonstrates that, having built a successful international operation around a strong brand name and a reputation for a quality product, companies are likely to seek ways of exploiting their position in the marketplace by starting new ventures which are able to develop under the umbrella of the existing profile. This may involve extending the product line, or even licensing the use of the name on other products (e.g. LEGO's licensing of its name to be used on a line of children's clothes: Hollensen, 1998, pp.312313), or moving into upstream or downstream activities. In the latter case such a move may enable the company to achieve a higher return from the market success of its product and name, and could contribute to greater control over these activities, compared to reliance on independent retailers.

In the situation we are considering of a move into, or extension of, retailing activities, it may lead to an increase in the company's share of value added in the total chain and allow it to expand its exposure at the retailing level on a much wider basis. The temptation to do so will be considerable if the company is unhappy about the pace of growth and degree of commitment within the existing retail arrangement for its products. Franchising allows greater direction over the development of retail operations compared to the use of an intermediary and independent retail outlets, and is often used as a way of accelerating retail expansion without having to become involved in day-to-day operations, while reducing the financial demands and risks associated with growth (Burt, 1993). Benetton has often been quoted as an example of a company which has been able to grow extensively and rapidly with minimal financial commitment in retail outlets because the 
individual franchisees (or licensees) have been responsible for their own financing (Bruce, 1987; D unkin, 1988; D apiran, 1992).

\section{Empirical Investigation}

\section{Methodology}

The Danish clothing and footwear industry was considered to be particularly suitable for an exploratory investigation of the move into international retail franchising because: (1) it is heavily internationalised and (2) it was known to have had substantial movement by companies from upstream to downstream activities, including some at the retail level. The empirical investigation consisted of two components: an industry survey and an indepth qualitative study of two companies.

The purpose of the industry survey was to provide a broad overview of the pattern of international development of Danish clothing and footwear companies and their use of franchising. The industry survey consisted of two steps: First, the overall industry pattern was established on the basis of secondary data. Second, based on this broad information a subgroup of companies involved in international franchising was contacted by a mail survey.

The population of firms was defined as those that currently or previously had been classified by 6-digit NACE industry/ sector codes (D B93-standard, NACE, 1993) as having production, design or wholesaling of clothing or footwear as their prime business activity. Thus, firms which had been classified as retailers on a continuing basis were not included in the study. A total of 60 companies were identified. $0 \mathrm{n}$ the basis of secondary sources (Kompass Denmark, CD -D irect, press releases, newspaper and business journal articles), the companies were grouped according to their international operation mode and product development stage as at April 1998. The sub-group of companies involved in international franchising was surveyed through a mailed questionnaire. In this questionnaire the companies were asked to provide details of their individual paths to international franchising.

Case studies of two companies were conducted in order to provide an in-depth understanding of the actual process of movement into international retail franchising (Patton, 1990; Y in, 1994). The qualitative study was based on company documentation (including a public 'offering circular') and semi-structured interviews with a manager in each of the two case companies. Furthermore, interviews were conducted with a 
representative from each of the two industry associations (association of manufacturers of textiles and clothing; and association of textile, clothing and footwear retailers), assisting triangulation. The purpose of these interviews was to elicit industry contextual information and an overview of the pattern and process of movement into international retail franchising from an association perspective.

\section{Results}

The composite pattern of internationalisation of the Danish companies is shown in Figure 3. Of the 60 companies in the industry, nine were found to be using international franchising. These companies were then contacted directly and requested to indicate the pattern of their international development. Four responses were received. Combined with the secondary data, and subsequent interviews with two of the companies, they revealed a general pattern in which the realisation of international franchising is preceded by a company transformation in terms of international operations and product development.

\section{FIGURE 3 ABOUT HERE}

The product development of the international franchisors appeared to pass through several stages before business format franchising was reached. Most of the franchisors-to-be started operations using their own brand. Some, however, did begin as suppliers to private label retailers. In these cases the product development transformation of the company had gone through all stages. Over a period of time, all of the companies developed concept sales - 'concept' in this case referring to something broader than the brand, including as well an expression of style and lifestyle appeal, reinforced through a product range, in-store presentation and promotional material. For the industry as a whole, the majority of the companies are private label suppliers (see Figure 3). The second largest group consists of business format franchisors, mostly the international group. A smaller group of very specialised companies are own brand suppliers, while even less are involved in concept sales.

With a single exception, all firms in the industry are involved in international operations (see Figure 3). Still, almost half of the companies' international operations are confined to exporting. One third of the companies have made upstream foreign direct 
investments (FD Is), in the form of wholesaling or subcontracting activities. A further one fifth (including the international franchisors) have undertaken downstream FD Is, through the establishment of company owned retail outlets. The overall pattern of establishment, without exception, has been for upstream FD Is to precede downstream FD Is.

\section{Case Analysis}

The two companies selected for detailed investigation were InWear and Carli Gry. Analysis was facilitated by the fact that both companies had listed on the Danish stock exchange in 1996, so that there was more detailed company documentation available than would normally be the case. As a supplement to this, interviews with a manager in each of the two companies were conducted in late May, 1998. Basic data regarding the two companies are provided in Table 1. The overall pattern and timing of international development for the two companies is shown in Figure 4.

\section{TABLE 1 ABOUT HERE}

\section{FIGURE 4 ABOUT HERE}

\section{The Case Companies}

The InWear Group began operations in D enmark in 1969. It listed on the Danish stock exchange in 1996, although one of the original co-founders retains more than $50 \%$ equity, and he is currently managing director of the company. Annual sales, at mid-1997, had reached 1.517 billion Danish crowns. Its clothes are sold under three brand names: InWear, Matinique and Part Two. Production was outsourced from the beginning, but related activities such as design, product development, and physical distribution are still handled within the company. Exports started in the year following establishment, 1970, and with steady growth the first foreign subsidiaries (primarily wholesaling function) were set up in Sweden and Norway in 1974. International outsourcing to sub-contractors in Portugal and Hong Kong also took place soon after the company's initial establishment. Sales have achieved considerable global dispersion, for example including Canada and Asia, although they are heavily concentrated in Europe (currently almost 90\% of total 
sales), with the bulk in the Scandinavian and Benelux countries, which were described as 'extended home markets'. Much of the foreign market activity is handled through eleven sales subsidiaries. Three additional foreign subsidiaries, in Portugal, Italy and Hong Kong, along with the Danish headquarters, co-ordinate materials purchases and contract manufacturing activities.

After initial discussions within the management group in the late 1970s regarding what was seen as the emergence of a trend from wholesaling to retailing by clothing companies, InWear set up its first company-owned and operated retail outlet in D enmark in 1980. The first international retail outlet was established in 1985. In 1990 the first move into international franchising activity took place. In contrast to the company owned retail outlets, the franchised independent retailers own the outlet, pay for the fixtures and fittings and information technology system themselves, and are responsible for their own purchases. They operate exclusively under the InWear format. There is not a standard contract between the parties - the level of InWear support is the subject of negotiation. In interview, the arrangement was described as a co-operation agreement. By mid-1997 the overall split between franchised and company-owned retail outlets was: 35 companyowned, 40 franchised (excluding shop-in-shop arrangements). Currently, the company has expressed a preference for own retail outlet development rather than franchising, although it has indicated that it expects to emphasise franchising more strongly in the future as its retail base, brands and knowledge of retail operations in foreign markets are more firmly established. In fact, for the first time its recent moves into the Austrian and Polish markets were accomplished initially by retailing operations, with more traditional wholesaling activities following. Nevertheless, in mid-1997 InWear's traditional wholesale trade represented $61 \%$ of total sales for the group.

Carli Gry International began operations as a single clothing shop in 1948 in Copenhagen. After take-over in 1973 by Klaus Helmersen (still majority shareholder and board member), it began to expand by developing a chain of company-owned clothing shops in Denmark (called House of Carli G ry) as well as undertaking wholesale sales to independent retailers in D enmark and Finland. These were soon expanded to a number of other countries and the first sales subsidiary was established in Norway in 1976. About 95\% of its sales in 1997 occurred under two brand names, Cottonfield and Jackpot. Annual sales, at the end of 1997, had reached 914.2 million Danish crowns. At the time of the investigation, Carli Gry was in the process of acquiring the Swedish sportswear 
company Peak Performance, which would add an expanded range of international operations and about 270 million Danish crowns in sales under the well established Peak Performance brand. Carli Gry product sales in 1997 took place in 20 countries via 15 wholly-owned foreign subsidiaries. All but 1\% of sales were to European countries, with the bulk (65\%) to Nordic countries, the Netherlands and the UK. A branch office in Turkey and a subsidiary in Hong Kong oversee production by sub-contractors in Turkey and Asia respectively. Like InWear, Carli Gry outsources all production, and has done so throughout its history except for a brief period in Poland when local production was undertaken as a result of local pressures and in response to the local tax regime.

The company began establishing retail outlets in foreign markets in 1985. More recently it has stated that it sees this path as a key part of its future international development. At the end of 1997 Carli Gry had 84 company-owned shops in 16 countries. The ultimate aim, stated in interview, was that these outlets should provide around $50 \%$ of total revenue. According to the company, this emphasis serves three primary purposes. First, they constitute a profitable business area. Secondly, they serve as a marketing tool towards consumers and other retailers. Finally, Carli G ry's own shops are used as a source of clear and precise marketing information' (Carli Gry Annual Report, 1997, p. 10). Despite this focus, traditional wholesale activities, like InWear, still constitute the bulk of company sales - representing almost 70\% at the end of 1997.

Carli Gry began international franchising operations in 1994. The franchisees are independent retailers who exclusively carry Carli Gry products. There is no royalty payment and the business is basically carried out on a wholesale basis. The franchisee pays for the fitting out of the shop and point-of-sale material. At the end of 1997 the company had 59 franchised shops (31 added in 1997). Although the company has clearly stressed its own retail outlets as the primary mode of international expansion, franchised outlets are viewed as a key additional arm of the drive into international retailing.

\section{Discussion}

While the two Danish case companies differ in the precise pattern of evolution of international operations, there are many similarities in their approach and the basis for the shift into international retailing and franchising. To some extent also they could be seen as indicative of the broader attempt by many clothing companies to move downstream into retailing operations (Lewis, 1993). Both company representatives stressed in 
interviews the importance of this shift because of the pressure being felt at their level from other low cost suppliers, while retailing outlets were increasingly being pre-empted by the growth of exclusive, competitive brand outlets. Further, in D enmark, independent retailers have been forming voluntary, co-operative buying groups and undertaking foreign contract manufacturing, thereby bypassing existing suppliers. The overall market for clothing was seen as splitting into two broad segments: a mass market, serving supermarkets, discounters and the like, with an emphasis on low prices; and a more specialised market, with emphasis on brands and lifestyle concepts, usually higher priced, and increasingly relying on specialised retail outlets that are company-tied. The case companies felt that they had no choice but to push further into the retail arena, to protect their access to the market. As an example of this concern, one of the interviewees commented that a large department store chain in Germany which it supplied was currently rationalising the number of suppliers as a cost cutting measure and the company was in danger of being dropped because it was a relatively small scale supplier.

The move into, or in Carli Gry's case expansion of, retail operations took place initially via the establishment of company-owned outlets, in both cases within Denmark first. The retail push by both of the case companies was further facilitated by the development of dedicated shop-in-shop outlets. The InWear representative commented that the move from wholesaling to retailing had been a difficult one for the company, requiring adjustments at many levels, and had created some 'tension' in the organisation. He said it had required a different approach to management, for example as a result of having to deal directly with consumers, cope with the high level of retail staff turnover, and become more heavily involved in training. With wholesaling, only a small sales staff was needed, because of the business-to-business marketing focus. Both interviewees stressed, however, that having their own outlets delivered a higher level of control over the way in which their lifestyle concepts were presented to consumers, and the value of having secure market outlets.

It was against this background that both case companies turned to franchising as an additional avenue for their push into international retailing activities. However, there was a degree of reluctance about this step: having their own retail outlets was clearly the preferred option. Nevertheless, there seemed to be a growing recognition of the place of franchising, such that, as one interviewee commented, it was 'now seen as the way to grow'. The reality of financing the building of a company-owned international retail chain 
was part of this interest. The Carli Gry representative summed up the franchising option as 'low risk and low investment', while 'probably' creating a more highly motivated operator compared to the company-owned situation. The InWear representative indicated that the company had gone into franchising 'too early'. It was described as being easier later because the company had a better base - better systems (eg information technology), the company was better known (partly because of its own retail outlets) and the company had better knowledge of foreign retail markets. He commented that in general the experience in retailing had been of benefit for the franchising activity. As a result, InWear planned a stronger emphasis on franchising in the next few years, although still with priority given to its own retail operation.

Both companies used their foreign subsidiaries to run the franchising activity in foreign markets, utilising the local/ regional market presence and knowledge base, within a framework of overall company supervision. Carli Gry's representative commented that the decision on whether to franchise or set up a company-owned outlet was left in the hands of each foreign sales subsidiary, within general head office guidelines regarding the number of each form, although in Spain and Finland the locals favoured franchising so the guidelines were relaxed.

For both case companies, therefore, the move into international franchising could be seen as an incremental move. On the surface it did involve the addition of a very different mode of foreign operation, but the way this was handled meant that the real extent of move was rather limited, and this is the way it was perceived by the companies. The demands of the move were reduced by the fact that the franchising package in each case was limited in scope, with a relatively simple agreement and lack of tight controls over the franchisee's operations. Both companies tended to see the franchise as another form of company controlled retail outlet, where they could call on existing foreign retailing experience. As well, they were able to make the move from an established foreign market presence in the form of their own foreign subsidiaries, with all of the local knowledge this implied. These subsidiaries also provided a ready made in-market vehicle for managing the ongoing foreign franchising activity, as their subsequent role confirmed. Their experience does demonstrate the way in which companies might accomplish the switch into international retail franchising, although much depends on the type of experience and foreign base of operations which has been established. Contrary to the reported French pattern (Lewis, 1993), Danish clothing companies, as exemplified by 
InWear and Carli Gry, do not seem to be using franchising as the initial or primary means of development of international retailing operations. Without a strong background of experience from developing and honing the use of the franchising package within the domestic context, they exhibit a lack of assurance and a certain reluctance about employing franchising as a major avenue of accelerated international retail expansion.

\section{Conclusion}

The move into international franchising from other forms of international operations would seem to be a potentially important phase in the overall development of international franchising. If companies can successfully handle this transition, and it becomes a path of wider use, it might provide further impetus to the growth of international franchising. An obvious barrier to this development would seem to be the lack of preceding experience in franchising and, therefore, the lack of franchising specific knowledge and skills, and package development, normally honed through the process of expansion in the home market.

Investigation of the pattern of internationalisation of Danish clothing and footwear companies revealed that, out of 60 companies in total in the industry, nine had reached what might be called an advanced stage where international franchising had become part of their international operations. Clearly, then, the shift has assumed some importance in this context. This was confirmed in the more detailed case investigations, which demonstrated that franchising had become increasingly important for the case companies in achieving international retail expansion. The Danish experience also indicated that the move into franchising was not perceived as a major or difficult one because of the preceding forms of 'preparation' - foreign subsidiary development for wholesaling and subcontracting purposes and the establishment of company owned retail outlets. These provided a base of foreign market and retail sector knowledge, and a readymade organisational base for handling the franchising activity. Further, the form of franchising in the two case companies was such that it limited the commitment to, and involvement in, the franchised operations. In explaining why their companies had used franchising, both case company representatives stressed the contribution to growth, while emphasising qualities of low investment and low risk.

In some respects the internationalisation patterns of the Danish clothing and footwear companies raise interesting questions about what is a 'normal' pattern of internationalisation (Luostarinen et al., 1994). High commitment operation modes in the 
form of foreign subsidiaries and own retail outlets precede low commitment franchising operations, contrary to the general pattern. It would seem that resource commitment and market risk considerations give way to learning and the development of a range of company competencies to enable the later use of franchising in the establishment chain. 


\section{References}

Alexander, N. (1996) International retail expansion within the EU and NAFTA. Europeen Business Reviev 96, 23-35.

Baroncelli, A. and Manaresi, A. (1997) Franchising as a form of divestment: an Italian study. Industrial MarketingManagement, 26, 223-235.

Bruce, L. (1987) The bright new worlds of Benetton. Intemational Management, November, 24-35.

Burt, S. (1993) Temporal trends in the internationalization of British retailing. Intemational Review of Retail, DistributionandConsumer Research, 3, 391-410.

Burton, F., Cross, A.R. and Rhodes, M. (1997) Foreign market servicing strategies of U.K. franchisors. In Global Business in the Information Age Proceedings of the 23rd. EIBA Conference, eds K. Macharzina, M.-J. O esterle and J. Wolf, pp. 798821. Stuttgart, D ec. 14-16.

Carli Gry International AS, Annual Repart, 1997, Copenhagen.

Dapiran, P. (1992) Benetton - global logistics in action. Intemational Jaumal of Physical Distribution andLogistics Management, 22, 7-11.

Dawson, J.A. (1994) Internationalization of retailing operations. Jaumal of Marketing Management, 10, 267-282.

D nes, A.W. (1992) Frandising A CaseStudyA pproad. Avebury, Aldershot.

Dunkin, A. (1988) The Benetton shopkeepers losing their shirts. Intemational Business Week, March 14, 58-59.

Fladmoe-Lindquist, K. (1996) International Franchising: Capabilities and development. Jaumal of BusinessV enturing 11, 419-438.

Framnes, R. and Welch, L.S. (1992) Entering international markets via franchising: the Norwegian experience with comparisons to Australia. In Problems and Prospeetsin Intemational Business Proceedings of the AIBSEAR Conference, eds O.H.M. Y au and W.G. Shepard, Brisbane, June 21-24, 582-585.

Granitsas, A. (1998) Back in fashion. FarEastemEconamicReview May 21, 52-54.

Hackett, D.W. (1976) The international expansion of U.S. franchise systems. Jaumal of Intemational Business Studies 7, 65-75.

Hollensen, S. (1998) Gldbal Marketing Prentice Hall Europe, Hemel Hempstead. 
Lewis, M. (1993) Selling Textiles and Clothing in France The Frandhise Rate Textiles Intelligence Limited and Economist Intelligence Unit, London, Textile O utlook Market Report No. 2636.

Luostarinen, R.K. (1979) Intemationalization of the Fim Helsinki School of Economics, Helsinki.

Luostarinen, R., Korhonen, H., Jokinen, J. and Pelkonen, T. (1994) Gldbalisation and SME. Ministry of Trade and Industry - Finland, Helsinki.

McCosker, C.F. and Walker, B.J. (1992) International expansion by Australian franchisors. Paper presented at the 12 th annual Babson College Entrepreneurship Conference, Fontainebleau, France, June.

McIntyre, F.S. and Huszagh, S.M. (1995) Internationalization of franchise systems. Jaumal of Intemational Marketing 3, 39-56.

NACE (1993) 6-digit sector nomenclature codes - D B93-standard.

Patton, M.Q. (1990) Qualitative Evaluation and Reserch Methods Sage Publications, Newbury Park, CA.

Petersen, B. and Pedersen, T. (1997) Twenty years after - support and critique of the Uppsala internationalisaton model. In The Nature of the Intemational Fimm eds I. Bjorkman and M. Forsgren, Copenhagen Business School Press, Copenhagen, 117-134.

Segal-Horn, S. and Davison, H. (1992) Global markets, the global consumer and international retailing. Jaumal of Gldbal Markeing 5, 31-61.

Treadgold, A.D. (1990) The developing internationalisation of retailing. Intemational Jamal of Reail andDistribution Management, 18, 4-11.

Walker, B.J. (1989) A Companison of Intemational vs Damestic Expansion by U.S. Frandise Systems International Franchise Association, Washington, DC.

Walker, B.J. and Etzel, M.J. (1973) The internationalization of U.S. franchise systems. Jaumal of Markeing 37, 38-46.

Welch, D.E. and Welch, L.S. (1996) The internationalization process and networks: a strategic management perspective. Jarmal of Intemational Markeing 4, 11-28.

Welch, L.S. (1990) Internationalization by Australian franchisors. Asia PaaficJamal of Management, 7, 101-121.

Yin, R.K. (1994) Case Study Resendr Design and Methods $2^{\text {nd }}$ edition. Sage Publications, Thousand $\mathrm{O}$ aks, CA. 
Table 1 Basic data regarding the two case companies

\begin{tabular}{|c|c|c|}
\hline Company data & InWear & Carli Gry \\
\hline Turnover (1997) & USD 262 m & USD 141 m \\
\hline $\begin{array}{c}\text { Number of employees } \\
\text { Proportion of foreign } \\
\text { sales }\end{array}$ & 1008 & 644 \\
\hline $\begin{array}{c}\text { Number of company- } \\
\text { owned outlets* }\end{array}$ & $90 \%$ & $82 \%$ \\
\hline $\begin{array}{c}\text { Number of franchised } \\
\text { outlets* }\end{array}$ & 35 & \\
\hline $\begin{array}{c}\text { Number of foreign } \\
\text { sales subsidiaries }\end{array}$ & 40 & \\
\hline
\end{tabular}

*Note: Excluding shop-in-shop arrangements.

Bent Petersen is Associate Professor of International Business at Copenhagen Business School, D enmark.

Lawrence S. Welch is Professor of International Marketing at the Norwegian School of Management (BI) in O slo and Adjunct Professor, University of Western Sydney-Nepean, Australia. 
